Indonesian Journal of Biotechnology, June, 2014

Vol. 19, No. 1, pp.79-90

\title{
Allozyme variation of the endemic and vulnerable Dyera lowii Hook.f. in Central Kalimantan: Implications for genetic resources conservation
}

\author{
Tri Suwarni Wahyudiningsih", Mohammad Naiem², Sapto Indrioko², \\ and Issirep Sumardi ${ }^{3}$
}

1) Faculty of Agriculture, Universitas Palangka Raya, Indonesia

2) Faculty of Forestry, Universitas Gadjah Mada, Yogyakarta, Indonesia

3) Faculty of Biology, Universitas Gadjah Mada, Yogyakarta, Indonesia

\begin{abstract}
Dyera lowii is an endemic and vulnerable tree species of commercial value as chewing gum found in peat swamp forests, scatteredly distributed in Sumatra, Kalimantan, and Peninsular Malaysia. Their existence is now under severe threat due to habitat conversion. This study is aimed to assess genetic diversity within four natural populations (Hampangen, Parahangan, Sebangau, Selat Nusa ) and one plantation in Central Kalimantan based on allozyme variation. Electrophoresis procedures were conducted with an isoelectric focusing polyacrylamide slab gel system. The result showed high genetic diversity $\left(H_{E}=0.52\right)$ and gene flow (3.402) seemed to be effective. A total of 14 alleles were found among all the analysed population. Mean number of alleles per locus $\left(A_{a}\right)$ was 3.206, and the effective number of alleles per locus $\left(A_{e}\right)$ was 2.21. Genetic differentiation between populations $\left(F_{S T}\right)$ was significant at the moderately level (0.0685). Most allozyme variation was found within population (93.2\%). Special attention is essential to conserve a private allele of Got-1-e (9\%) at Selat Nusa population. Sebangau population missed the alleles of Est-2-b and Got-1-a, as found in other populations. Selat Nusa population is expected to enhance the effective management for genetic resources conservation of this vulnerable species in the future.
\end{abstract}

Keywords: allozyme, genetic diversity, genetic differentiation, populations, Dyera lowii.

\section{Introduction}

The global centre of biodiversity of tropical peat swamp forests lies in the IndoMalayan region where these unique habitats impact the functioning of ecosystems far beyond their borders through their influences on climate and hydrology. These forests support a biological resource of global importance, yet on a daily basis they are being rapidly degraded and destroyed (Yule, 2010). Several efforts at rehabilitation of peat swamp forests that have been degraded by drainage, fire and logging or converted to agriculture are under way in Central

\section{* Corresponding author:}

TriSuwarni Wahyudiningsih, Faculty of Agriculture, Jalan Yos Sudarso Kompleks Tunjung Nyaho, Palangka Raya, Kalimantan Tengah 73112.

E-mail: tri.s.w.basuki@gmail.com
Kalimantan (Australian Orangutan Project 2008; Dohong 2008).

Rehabilitation of the Mega Rice Project in Borneo (described by Dohong 2008) is supported by Presidential Instruction No 2/2007, and it aims to restore and conserve $80 \%$ of the former Mega Rice area. Rehabilitation involves restoration of hydrology through dam construction, blocking of the canals that were built to drain the peatlands, followed by replanting with indigenous species of commercial value such as Dyera lowii, Alstonia pneumatophora, and Garcinia spp. Use of these commercial species such as these, encourages the local people to conserve the forests in perpetuity (Yule, 2010).

Dyera lowii Hook.f. is a common tree species in the peat swamp forests of Sumatra, 
Kalimantan, and Malaysia. This species producing the first NTFPs (Non Timber Forest Products) based on Minister of Forestry Decree No. 21/2009. NTFPs are regarded as a means of subsistence and an income generation resource for people living in or near forests, and are thought to reduce the depletion of natural tropical forests by humans (Donovan and Puri, 2004). NTFPs are obtained from forest resources, including resins, latex, bark, roots, seeds, flowers, fruits, leaves, mushrooms and other nonwood plant parts. Valuable latex is harvested from the stem of $D$. lowii, that is used in chewing gum. These wood are prefered for making all component acoustic instruments of violin and guitar except for the top plate of violin (Sedik et al., 2010). In addition, this species is categorized as vulnerable (VU A1cd) by IUCN or International Union for Conservation of Nature (2010). Despite its great economic value, its ecological functions and conservation in peat swamp forest, environmental importance of the species, the level of risk, this endemic tree species has been poorly studied in regards genetic diversity across its distribution.

The existence of diversity is the main prerequisite of the capability of a living system to adapt the changes of environment on all hierarchical levels of biological organization from a population through a community to an ecosystem (Vandergast et al., 2008). However, in consideration of the future restoration and long-term survival of this vulnerable species in the wild, conservation strategies and policies are further required to help effectively management on remaining and transplanted individuals in order to maintain their genetic basis and evolutionary potentials.

Allozyme variations, which have been widely applied to examine population genetic variations since the late1960s, are still powerful in current population genetic analyses. They are almost invariably codominant, simple and despite being traditionally recognized as markers of neutral differences. Thus, the variants are potentially useful for plant and animal conservation and management applications to understand the genetic diversity of populations that are locally adapted (Ridgway, 2005). The amount and pattern of genetic diversity is needed to develop conservation strategies. In the present study, allozyme variations were used to detect the genetic diversity and differentiation of five D. lowii populations in Central Kalimantan. With the genetic information obtained, the possible management of these populations could enhance the effective management of the transplanted populations and individuals of $D$. lowii.

\section{Material and Methods \\ Plant material and extraction.}

Geographical locations of D. lowii sampled population (Table1). Leaf samples of D. lowii were collected from five populations representing to Central Kalimantan i.e. four populations of natural peat swamp forest of Hampangen, Parahangan, Sebangau, Selat Nusa and one plantation population on Palangka Raya (Fig. 1). Sample trees were chosen at random and separated by a minimum distance of $15 \mathrm{~m}$. The strategy for sampling trees involved the collection of single individuals for each population

Table 1. Geographical location of D. lowii sampled populations

\begin{tabular}{lcllc}
\hline \multicolumn{1}{c}{ Population } & $\begin{array}{c}\text { Number of } \\
\text { samples }\end{array}$ & \multicolumn{1}{c}{ Latitude } & \multicolumn{1}{c}{ Longitude } & $\begin{array}{c}\text { Altitude } \\
(\mathrm{m})\end{array}$ \\
\hline Hampangen & 55 & $1^{0} 52^{\prime} 0-1^{0} 54^{\prime} 0^{\prime \prime}$ & $113^{0} 28^{\prime} 0^{\prime \prime}-113^{0} 32^{\prime} 0^{\prime \prime}$ & $34-60$ \\
Parahangan & 54 & $1^{0} 50^{\prime} 40^{\prime \prime}-1^{0} 50^{\prime} 50^{\prime \prime}$ & $113^{0} 57^{\prime} 25^{\prime \prime}-113^{0} 57^{\prime} 25^{\prime \prime}$ & $31-52$ \\
Sebangau & 55 & $2^{0} 18^{\prime} 15^{\prime \prime}-2^{0} 19^{\prime} 02^{\prime \prime}$ & $113^{0} 50^{\prime} 0^{\prime \prime}-113^{0} 54^{\prime} 35^{\prime \prime}$ & $12-51$ \\
Selat Nusa & 54 & $2^{0} 25^{\prime} 41^{\prime \prime}-2^{0} 32^{\prime} 55^{\prime \prime}$ & $114^{0} 11^{\prime} 31^{\prime \prime}-114^{0} 12^{\prime} 09^{\prime \prime}$ & $10-25$ \\
Plantation & 54 & $2^{0} 9^{\prime} 44^{\prime \prime}-2^{0} 9^{\prime} 51^{\prime \prime}$ & $113^{0} 51^{\prime} 16^{\prime \prime}-113^{0} 51^{\prime} 20^{\prime \prime}$ & $60-61$ \\
\hline
\end{tabular}


categories. In total, leaf material from 266 individuals were assessed, 211 individuals from natural forest and 55 individuals from plantation.

\section{Allozyme electrophoresis}

Electrophoresis procedures were conducted with an isoelectric focusing polyacrylamide slab gel system following

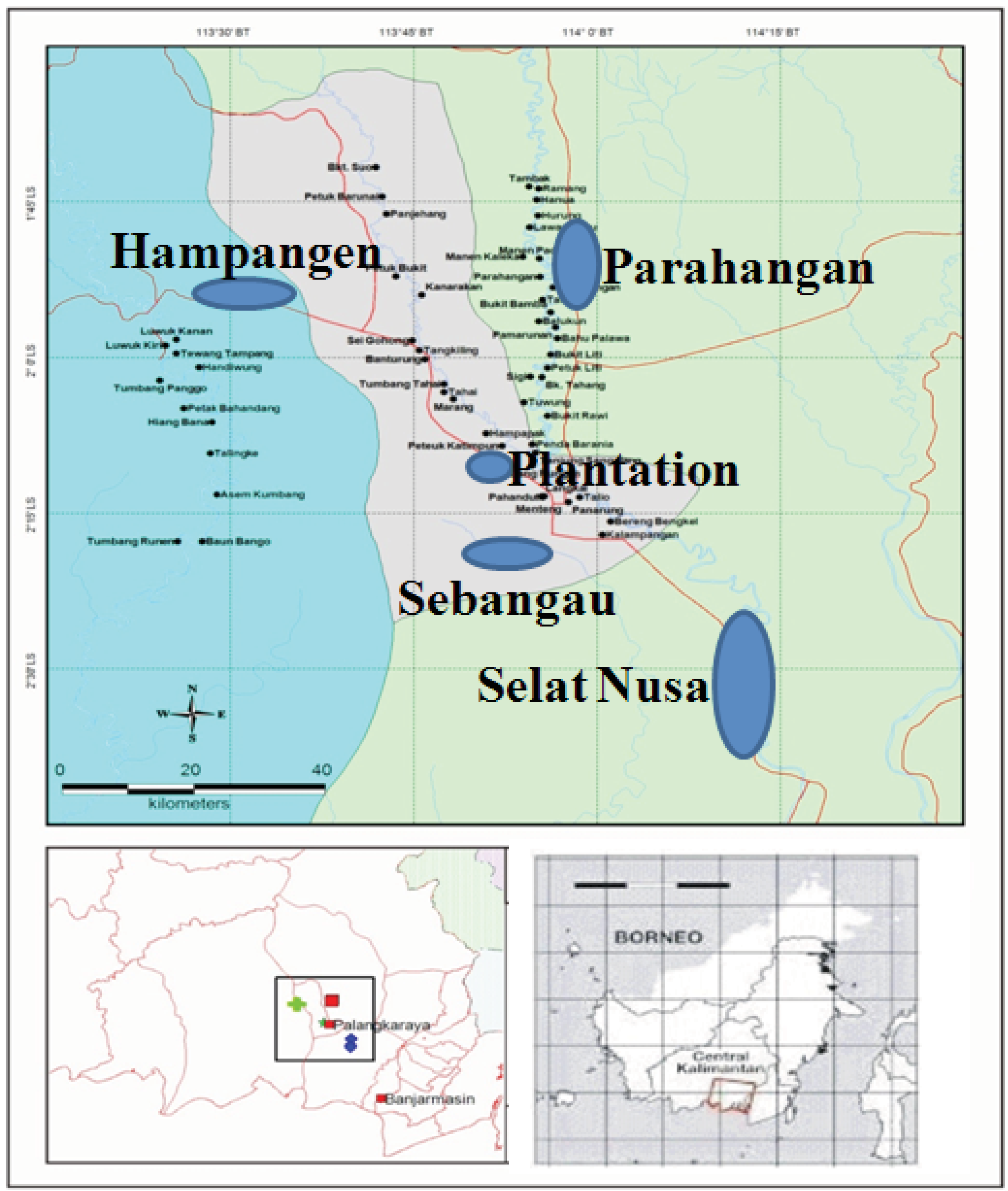

Figure 1. Location of D. lowii Hook.f. sampled populations within the distribution of the species in Central Kalimantan. 
the procedure of Wendel and Weeden (1989). Electrophoresis of enzymes extracted from young leaf of individual plants was carried out in vertical plates of $7.5 \%$ polyachrilamyde gel. The conditions of extraction, electrophoerethic fractioning, histochemical staining of enzymes, allele identification and nomenclature. The following seven enzymatic systems were used as markers in the given investigations: Shikimate dehydrogenase (SHD; EC 1.1.1.25), NAD (P)H-Diaphorase (DIA; EC 1.6.2.2), Glutamate oxaloacetate transaminase (GOT: EC 1.11.1.7), Acid phosphatase (ACP; EC 3.1.3.2), 6-Phosphogluconate dehydrogenase (6-PG; EC 1.1.1.44), Esterase (EST; EC 3.1.1), dan Peroxidase (POD; EC 1.11.1.7).

Enzymes were extracted from the young leaves of each plant on an ice plate. Each enzyme, gene loci and alleles were inferred and labeled following numerical and alphabetical sequence, respectively. Electrophoretic isozyme phenotypes (hereafter zymograms) were genetically interpreted as one-banded homozygotes or multiple-banded heterozygote.

\section{Data analysis}

Every enzyme system in each gel was observed to determine the related allele based on the banding pattern and to calculate the relative value to bromophenol blue front $\left(R_{f}\right.$ value). The alleles were inferred from the observed banding patterns and constructed as diploid genotypes.

POPGENE version 1.31 (Yeh et al., 1999) was used to calculate the standard measure of genetic diversity, including allele frequency of each locus, number of alleles per locus $\left(A_{a}\right)$, number of effective alleles per locus $\left(A_{e}\right)$, percentage of polymorphic loci $(P P L)$, observed heterozygosity $\left(H_{O}\right)$ and expected heterozygosity $\left(H_{E}\right)$.

The measure of population genetic differentiation was analyzed using the standard method of the estimation of Nei's (Nei, 1987), $F_{S T}$, using POPGENe program. $F_{S T}$ is often designated as the latter for ease of discussion. UPGMA dendrogram of relationships between populations based on the allele frequency data and Nei's standard genetic distances (Nei, 1972) was constructed with POPGENE program.

\section{Results and Discussion Genetic variation}

Seven enzymatic systems were used as markers in the given investigations:: EST, GOT, SHD, DIA, 6-PG, ACP, and POD. The banding pattern of DIA, SHD, and POD showed monomorphisms. Enzyme systems of 6-PG and ACP were polymorphic, resolved into no clear and no consistent while the banding pattern of EST and GOT showed polymorphisms, resolved into clear and consistent (Fig. 2 and 4). The seven enzyme systems prescreened, two resolved into clear and consistent banding patterns and were used for genetic analysis are were EST and GOT.

The examples of banding patterns EST can be shown in Fig. 2 and GOT in Fig. 4. A total of 14 alleles were found in all population, except Sebangau population. Based on $R_{f}$ length percentage banding pattern of EST were distributed into three loci as follows locus Est-1 (four alleles), locus Est-2 (three alleles), and locus Est-3 (two alleles) (Fig. 3). The $R_{f}$ length percentage banding pattern of GOT are showed only one locus (Got-1)

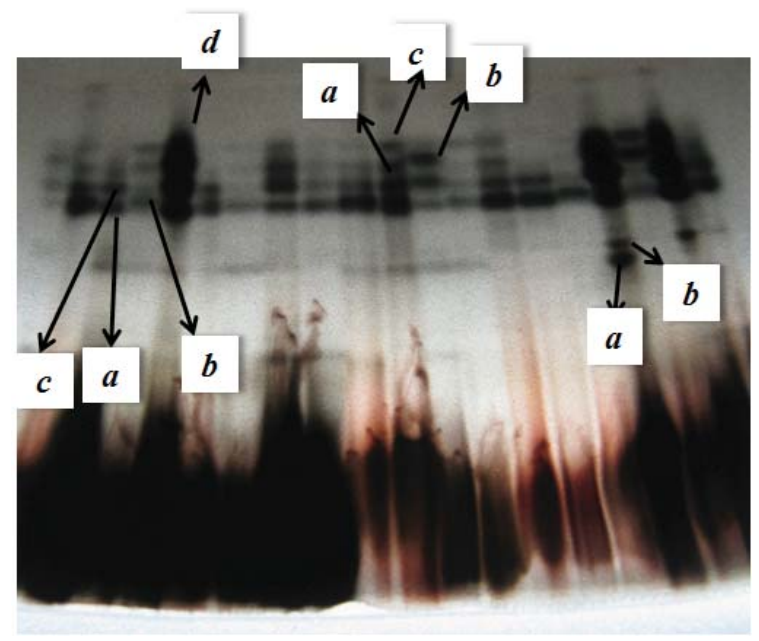

Figure 2. Examples of banding patterns of EST resulted by Electrophoresis procedures on D. lowii. 


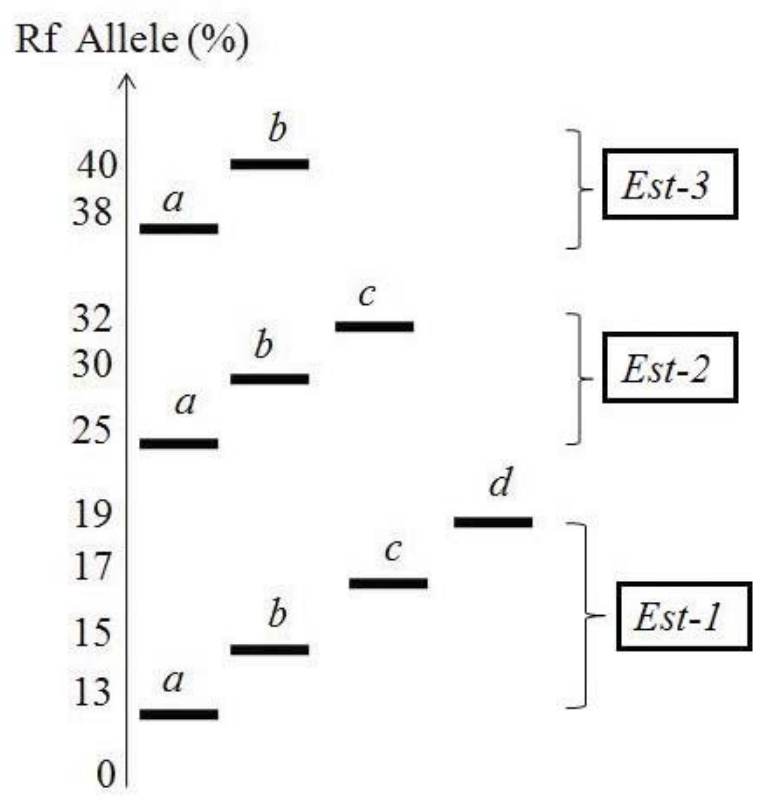

Figure 3. Allele distribution of locus of Est-1, Est-2, and Est-3.

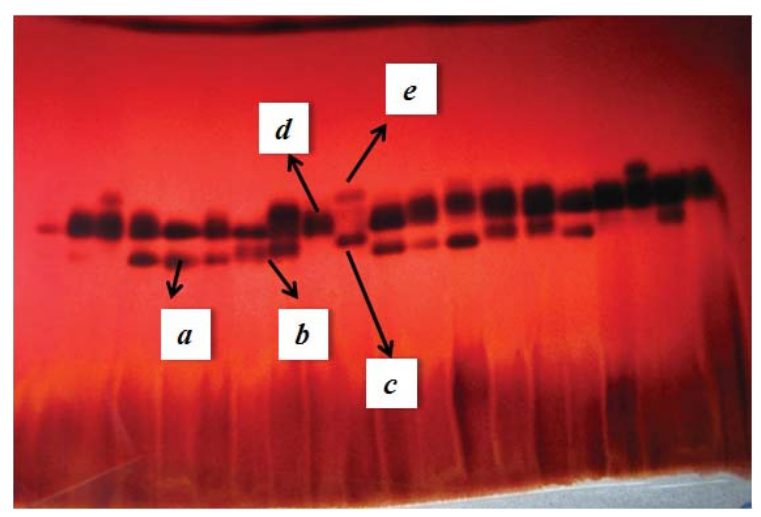

Figure 4. Examples of banding patterns of GOT resulted by Electrophoresis procedures on D. lowii.

consisted of five alleles (Fig. 5 ).

Distribution of allele frequencies can be shown in Table 2. The population of Sebangau exhibited the rare allele Est-1-a (0.011) and Est-1-d (0.011). Populations of Selat Nusa, Sebangau and plantation have different common allele of locus Est-3 (Est$3-a$ allele) in comparison with Hampangen population (Est-3-b allele). The alleles of Est2- $b$ and Got-1-a were found in all populations except of Sebangau population. Population of Selat Nusa was exhibited the presence of

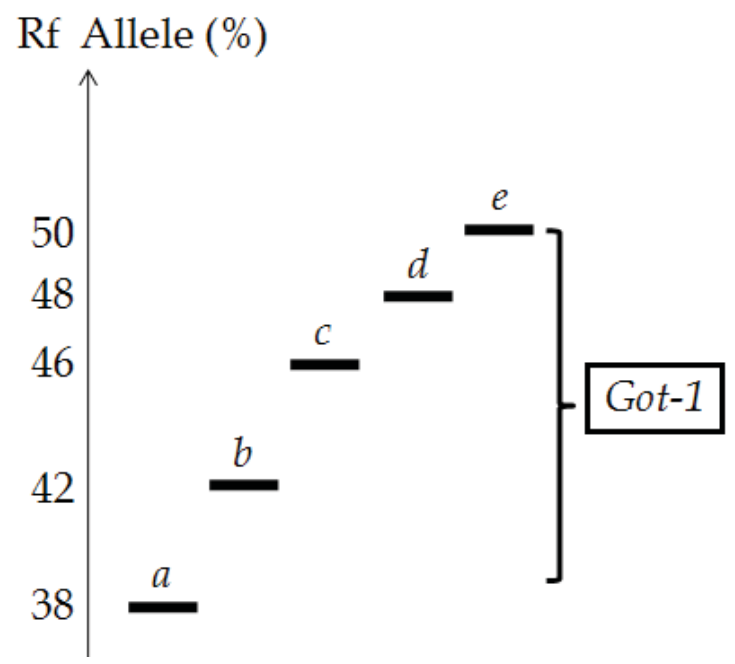

Figure 5. Allele distribution of locus of Got-1.

14 allele. Populations exhibited the presence of the private allele Got-1-e was Selat Nusa population (0.093).

The value percentage of locus polymorphic shown $100 \%$ in all populations. Mean value of $A_{e^{\prime}} H_{O}$ and $H_{E}$ were 2.202 (1.784-2.503), 0.634 (0.532-0.739) and 0.521 (0.422-0.596), respectively (Table 3). Mean observed heterozygosity $\left(H_{0}\right)$ was higher than mean expected heterozygosity $\left(H_{E}\right)$ in all populations. The Parahangan population showed greater genetic diversity $\left(A_{e}=2.503\right.$, $\left.H_{E}=0.739, H_{O}=0.596\right)$ than Selat Nusa population $\left(A_{e}=2.439, H_{E}=0.721, H_{O}=0.573\right)$. Nevertheless, Parahangan population exhibited lower number allelic per loci (3.250) than Selat Nusa population (3.500), but Selat Nusa population has the private allele Got1-e. So that, Selat Nusa was the center genetic diversity of $D$. lowii.

As an endemic species in peat swamp forest, D. lowii is characterized by high levels of allozyme diversity at both the species and population levels, expected heterozygosity $\left(H_{E}=0.521\right)$, number of alleles per locus $\left(A_{a}=3.206\right)$ and mean percentage of polymorphic loci $(P P=100 \%)$ at the species level (Table 3) were all higher than those reported for other endemic plant species 
Wahyudiningsih et al.

I.J. Biotech.

Table 2. Distribution of allele frequencies of four polymorphic loci from five D. lowii populations.

\begin{tabular}{|c|c|c|c|c|c|c|}
\hline \multirow{2}{*}{ Locus } & \multirow{2}{*}{ allele } & \multicolumn{5}{|c|}{ Population } \\
\hline & & Hampangen & Parahangan & Sebangau & Selat Nusa & Plantation \\
\hline \multirow[t]{5}{*}{ Est-1 } & & $n=54$ & $\mathrm{n}=53$ & $\mathrm{n}=49$ & $n=53$ & $\mathrm{n}=53$ \\
\hline & $a$ & 0.075 & 0.047 & 0.011 & 0.217 & 0.217 \\
\hline & $b$ & 0.648 & 0.415 & 0.678 & 0.396 & 0.377 \\
\hline & c & 0.204 & 0.377 & 0.3 & 0.274 & 0.274 \\
\hline & $d$ & 0.083 & 0.161 & 0.011 & 0.113 & 0.132 \\
\hline \multirow[t]{4}{*}{ Est-2 } & & $\mathrm{n}=55$ & $\mathrm{n}=54$ & $\mathrm{n}=49$ & $\mathrm{n}=54$ & $\mathrm{n}=54$ \\
\hline & $a$ & 0.546 & 0.417 & 0.582 & 0.417 & 0.417 \\
\hline & $b$ & 0.027 & 0.111 & - & 0.083 & 0.083 \\
\hline & c & 0.427 & 0.472 & 0.418 & 0.5 & 0.5 \\
\hline \multirow[t]{3}{*}{ Est-3 } & & $\mathrm{n}=53$ & $n=54$ & $\mathrm{n}=49$ & $\mathrm{n}=54$ & $\mathrm{n}=54$ \\
\hline & $a$ & 0.142 & 0.407 & 0.653 & 0.667 & 0.657 \\
\hline & $b$ & 0.858 & 0.593 & 0.347 & 0.333 & 0.343 \\
\hline \multirow[t]{6}{*}{ Got-1 } & & $\mathrm{n}=55$ & $\mathrm{n}=54$ & $\mathrm{n}=55$ & $\mathrm{n}=54$ & $\mathrm{n}=54$ \\
\hline & $a$ & 0.036 & 0.148 & - & 0.018 & 0.009 \\
\hline & $b$ & 0.082 & 0.222 & 0.163 & 0.176 & 0.074 \\
\hline & c & 0.109 & 0.093 & 0.283 & 0.074 & 0.083 \\
\hline & $d$ & 0.773 & 0.537 & 0.554 & 0.639 & 0.834 \\
\hline & $e$ & - & - & - & 0.093 & - \\
\hline
\end{tabular}

$H_{E}=0.138, A=1.76$ and $P P=48.1 \%$ (Hamrick and Godt, 1989, 1996a) and Instia bijuga $\left(H_{E}=0.409, A_{a}=2.49\right.$, and $\left.P P=96.4 \%\right)$ using isozyme (Mahfudz, 2011).

The values of expected heterozygosity of D. lowii $\left(H_{E}=0.521\right)$ was higher than the endemic species level in peat swamp forest of Gonystylus bancanus $\left(H_{E}=0.1894\right)$ using RAPD (Kusumadewi et al., 2010) and other tropical forest i.e Alstonia sp. $\left(H_{E}=0,247\right)$ using RAPD (Hartati et al., 2007), and Shorea leprosula $\left(H_{E}=0.406\right)$ using isozyme (Lee et al., 2000; Finkeldey, 2007). The $H_{E}$ value of $D$. lowii was lower than Hevea brasiliensis $\left(H_{E}=0.742\right)$ (Le Guen et al., 2010) and a threatened tree Dalbergia nigra $\left(H_{E}=0.735\right)$ using microsatellite (Resende et al., 2011).

Therefore, contrary to conventional expectations of lower genetic diversity levels for endemic species, the present results support the hypothesis that endemic plant species do not always harbor less total allozyme variation than more widespread species, as concluded in some recent studies (e.g., Delgado et al.,1999; Gonzales-Astorga and Castillo-Campos, 2004; Torres-Diaz et al., 2007). High genetic diversity in endemic species is commonly associated with unique species characteristics of life history, breeding system, and mode of reproduction (Hamrick and Godt, 1996a, 1996b). High levels of genetic variation are important because they provide the ability for tree species to adjust to new environments, such as the shifting climate and more variable weather conditions caused by elevated $\mathrm{CO}_{2}$ levels and global warming, allowing local adaptation and the migration of better-suited provenances along ecological gradients (Bawa and Dayanandan 1998; AttaKrah et al., 2004; Williams et al., 2007; Aitken et al., 2008; Dawson et al., 2009).

D. lowii is a long-lived woody plant, high seed production, the seeds have a wing, all morphological adaptations to wind dispersal. How effetive this can be when on many occasions having found seeds on the ground, we have subsequently been unable to find the parent plant, suggesting the plant might be quite far away (Midleton, 2007). All of these characteristics are probably responsible for the high genetic diversity retained in $D$. lowii populations. Therefore, long-term adaptive evolution in highly heterogeneous in peat swamp forest possibly contributes greatly 
Table 3. Descriptive summary of the genetic statistics of five populations of $D$. lowii in Central Kalimantan. $A a$, allele numbers per locus; $A e$, effective number of allele per locus; $P$, percentage polymorphic loci; $H_{0^{\prime}}$ observed heterozygosity; $H_{E^{\prime}}$ expected heterozygosity.

\begin{tabular}{lccccc}
\hline \multicolumn{1}{c}{ Population } & $A_{a}$ & $A_{\rho}$ & $P P L$ & $H_{O}$ & $H_{F}$ \\
\hline Hampangen & 3.250 & 1.784 & 100 & 0.532 & 0.422 \\
Parahangan & 3.250 & 2.503 & 100 & 0.739 & 0.596 \\
Sebangau & 2.750 & 2.003 & 100 & 0.533 & 0.499 \\
Selat Nusa & 3.500 & 2.439 & 100 & 0.721 & 0.573 \\
Plantation & 3.250 & 2.276 & 100 & 0.642 & 0.513 \\
Mean & 3.206 & 2.202 & 100 & 0.634 & 0.521 \\
\hline
\end{tabular}

to the high level of allozyme variations of D. lowii populations detected in the present study.

\section{Differentiation and Genetic Structure}

Investigation of the fixation index $\left(F_{I S}\right)$ showed significantly negative values -0.228 ( Table 4), suggesting significant excesses of heterozygotes in all populations. It might be due to assortative mating and selection (Yeh, 2000; Lowe et al., 2004). The $F_{I S}$ value is similar to Instia bijuga (-0.224) using isozyme (Mahfudz, 2011). The $F_{I S}$ value was higher than of a Neotropical Forest Pioneer Tree Vochysia ferruginea in the secondary forest populations observed at Tirimbina $\left(F_{I S}=-0.136\right)$ and Ladrillera $\left(F_{I S}=-0.157\right)$ (Davies et al., 2010). $F_{I T}$ showed the relative individual inbreeding significantly negative value $(-0.143)$ in all loci (Table 4$)$. The $F_{I T}$ value is similar to Instia bijuga (-0.136) using isozyme (Mahfudz, 2011).

$N m=$ Gene flow estimated from $F_{S T}=0.25(1$ $\left.-F_{S T}\right) / F_{S T}$.

Genetic differentiation between populations was evaluated using $F_{S T}$ (Wright,

Table 4. Value of $F_{I S^{\prime}} F_{I T^{\prime}}, F_{S T}$ and $N_{m}$ on loci.

\begin{tabular}{cccccl}
\hline Locus & Sample Size & $F_{I S}$ & \multicolumn{1}{c}{$F_{I T}$} & $F_{S T}$ & \multicolumn{1}{c}{$N_{m}{ }^{*}$} \\
\hline EST-1 & 528 & 0.247 & 0.375 & 0.17 & 1.217 \\
EST-2 & 532 & -0.701 & -0.676 & 0.014 & 16.682 \\
EST-3 & 516 & -0.106 & -0.053 & 0.048 & 4.975 \\
GOT & 526 & -0.252 & -0.187 & 0.052 & 4.535 \\
Mean & 526 & -0.227 & -0.143 & 0.068 & 3.416 \\
\hline$N_{m}=$ Gene flow estimated from Fst $=0.25(1$ - Fst $) /$ Fst.
\end{tabular}

1951), and its significance of deviation from zero was tested based on 1,000 permutations. The value of $F_{S T}$ was moderately differentiated $\left(F_{S T}=0.068\right)$, shown in Table 4. It means, most allozyme diversity was found within population (93.2\%) and among population $(6.85 \%)$, indicating that high genetic diversity is maintained within rather than among populations.

Based on allozyme genetic data regarding seed plants, Hamrick and Godt (1996b) showed that wind-pollinated and outcrossing species usually have low values of $G_{S T}$ values (approx. 0.094). In the present study, the population genetic differentiation of $D$. lowii indicated moderately differentiated $\left(F_{S T}=0.068\right)$ shown in Table 4. A windpollinated and long-lived woody species usually have weak genetic differentiation. In wind-pollinated, long-lived woods, the average $\mathrm{F}_{\mathrm{ST}}$ values tend to be low (Duminil et al., 2009), $F_{S T}=0.028$ in Cryptomeria Japonica (Takahashi et al., 2005), the average $G_{S T}=0.073$ in Gymnosperms (Hamrick et al., 1992). The moderately level was similar to seedling population of Vochysia Ferruginea $\left(F_{S T}=0.069\right)$ at Ladrillera (Davies et al., 2010) and a threatened tree Dalbergia nigra $\left(F_{S T}=0.088\right)$ in the Brazilian Atlantic Forest (Resende et al., 2011). These values are within the range of differentiation found in other tropical tree populations, where low differentiation was found for Dinizia excelsa $\left(F_{S T}=0.00167\right)$ (Dick et al., 2003a) and high levels of differentiation have been found for Caryocar brasiliense $\left(F_{S T}=0.29\right)$ (Collevatti et al., 2001), Taxodium distichum shown strong genetic differentiation 
Table 5. Genetic distance Nei's Unbiased Measures Genetic Distance (Nei, 1987).

\begin{tabular}{lccccc}
\hline \multicolumn{1}{c}{ Population } & Hampangen & Parahangan & Sebangau & Selat Nusa & Plantation \\
\hline Hampangen & $* * * *$ & & & & \\
Parahangan & 0.071 & $* * * *$ & & & \\
Sebangau & 0.149 & 0.081 & $* * * *$ & & \\
Selat Nusa & $\mathbf{0 . 1 7 5}$ & 0.059 & 0.055 & $* * * *$ & \\
Plantation & 0.161 & 0.076 & 0.077 & $\mathbf{0 . 0 0 8}$ & $* * * *$ \\
\hline
\end{tabular}

between populations $F_{S T}=0.208$ (Tanaka et al., 2012), and Gonystylus bancanus $\left(G_{S T}=0.9956\right)$ (Kusumadewi et al., 2010).

The moderately differentiated among population of $D$. lowii could be caused of gene flow process. Gene flow could be influenced by tree individual self, i.e mating system, landscape and habitat (Lowe et al., 2004). The estimation of gene flow $\left(N_{m}\right)$ was 3.402 (Table 4), resulting from $F_{S T}$ values suggested a high level of gene exchange among the four natural populations and one plantation.

The values of pairwise genetic distances shown in Table 5. The highest of genetic distances was observed between the populations of Hampangen and Selat Nusa $(0.175)$ with the highest distance $( \pm 92 \mathrm{~km})$. The smallest of genetic distances was observed between the populations of Selat Nusa and Forest plantation (0.008). Clustering of populations was mainly associated with their location. As shown in Figure 6, populations of Hampangen and Parahangan conformed a cluster by genetic distance of 0.071 . Base on observations, the distance of both population $50 \mathrm{Km}$ and continuous populations. The result found in Sebangau showed as the groupe of

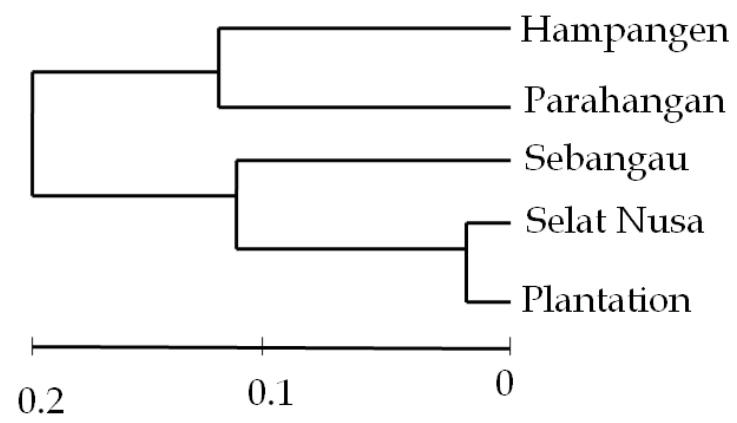

Figure 6. Dendrogram based Nei's (1987) genetic distance
Selat Nusa and plantation because to find out higher of allele frequencies (Ae) of Est-3-a than Est-3-b, and contrary the population of Hampangen and Parahangan (Table 2), the distance between Sebangau and Selat Nusa was $40 \mathrm{~km}$ and the genetic distance was 0.555. The populations of Parahangan and Selat Nusa have a same stream of Kahayan river by distance of $80 \mathrm{~km}$ between them. Parahangan and Selat Nusa populations have a genetic distance (0.059) which is lower than the genetic distance between Selat Nusa and Hampangen population (0.175) which is not the river flow. Population of Selat Nusa and plantation conformed a cluster. Nevertheless, seeds were planted as plantation were not from Selat Nusa population, but these were from Sampit population (Suyitno, 2013; personal communication).

This was further confirmed from the high gene flow (Nm) of 3.402. Moreover if $\mathrm{Nm}<1$, then local populations tend to differentiate; if $\mathrm{Nm} \geq 1$, then there will be little differentiation among populations and migration is more important than genetic drift (Wright, 1951). In accordance with genetic structure results, estimates of contemporary gene flow based on assignment tests suggested that genetic connectivity among populations is still high. Consequences of landscape alterations in plants are correlated with their life history characteristics (Sork and Smouse 2006; Aguilar et al. 2008), especially their mechanisms of seed and pollen dispersal. Seeds of D. lowii are wind-dispersed (Midleton, 2007) and it has been reported that native bees are the main pollinator (Wasis; personal communication). As expected by the species dispersal agents, pollen contribution to historical gene flow was much higher than 
seed contribution. Parentage assignments in tropical trees have demonstrated that insect pollen dispersal range is often greater than traditional estimates have shown, with mean pollination distances of hundreds of meters and maximum distances reaching up to 14 km (Nason et al., 1998; Hardesty et al., 2006; Hanson et al., 2008). In addition, some studies described an increase in recent gene flow among fragments in the insect pollinated trees of Dinizia excelsa (Dick, 2001), Swietenia humilis (White et al., 2002) and Dipteryx panamensis (Hanson et al., 2008). Increasing gene flow in $D$. lowii could also be determined by long-distance seed dispersal, as reported for a wind-dispersed species (Bacles et al., 2006).

Hughes et al. (1994) concluded that seeds larger than $100 \mathrm{mg}$ tend to be adapted for dispersal by vertebrates, while those smaller than $0.1 \mathrm{mg}$ tend to be dispersed unassisted. Most seeds, however, are between 0.1 and $100 \mathrm{mg}$; in this range all dispersal modes are feasible. $D$. lowii have dehiscent fruits and wind blown seed with weight of about 1-10 mg. Nevertheless, the success of effective long-distance seed dispersal are variable depending on other ecological and physiological conditions. Typically, the wind-dispersal seeds of $D$. lowii individuals usually settle within $50 \mathrm{~m}$ or may be prevalent $300-400 \mathrm{~m}$ from the parent plants (Handadhari, 2004). These characteristics are important contributors to reduce gene flow among populations, as evidenced by the significant by distance pattern occurring in peat swamp forest.

\section{Implications for conservation}

The results obtained in this study appear to be encouraging regarding the survival of D. lowii. The species still harbors high genetic diversity and gene flow seems to be effective. Thus, the recent vulnerable of some populations because of human-mediated activities could be counterbalanced by gene exchange among remnant populations or oil-palm plantations. In addition, Indonesia is the world's largest palm-oil producer, and it is predicted that a further 6Mha of (primarily forested) land will be converted to oil-palm plantations by 2020, with half of this on peatland (Hooijer et al., 2006).

Conservation of D. lowii with rehabilitation of the peat swamp forest in Central Kalimantan is supported by Minister of Forestry Decree No. P. 55/MenhutII/2008. It aimed to rehabilitate and to conserve the develoment peatland area in Central Kalimantan by 2007-2017, i.e. activity restoration community structure and forest vegetation, activity of ecosystem revitalisation and forest function as Enrichment planting i.e:, D. lowii, Shorea belangeran, Gonystylus bancanus replanted along the edge primary trunk ex MRP (Mega Rice Project). In addition of the policies of Presidential Decree No. 3/2012: conservation of biodiversity of plants endemic areas and rehabilitation of degraded areas of protected works. On other hand, low-intensity logging which retains some proportion of reproductive trees, followed by activity that accelerate natural or silviculturally induced $D$. lowii regeneration in peat swamp forest and plantation, may represent the best strategy for combining conservation and economic use of $D$. lowii with increasing human pressure. These activities support sustainability of high genetic variation of $D$. lowii.

Nevertheless, land use in this region has intensified over the years, and the absence of adequate habitat for recolonization is potentially hazardous in the long term. Our allozyme analysis based on five populations have the moderately level coefficient of genetic differentiation among population and the fixation index $\left(F_{I S}\right)$ showed significantly negative values $(-0.2288)$, suggesting significant excesses of heterozygocity in all populations. The value $N m$ (3.402) $\geq$ 1 , then there will be little differentiation among populations and migration is more important than genetic drift (Wright, 1951). Estimates from the $F_{S T}$ value indicated that five populations would adequately represent 
Wahyudiningsih et al.

$93.2 \%$ of the genetic diversity attributable to most common alleles. Based on genetic diversity of the others, and degree of threat, priority populations to monitor could be Sebangau population because the alleles absence of Est-2- $b$ and Got-1- $a$, the rare allele Est-1-a (1\%) and Est-1-d (1\%). In addition, Hampangen population has the lowest level of genetic diversity.

The conservation efforts of $D$. lowii must be done so that no such species that already have low genetic diversity i.e $H_{E}=0.17$ of the threatened tree daisy Olearia gardneri (Barnoud and Housliston, 2010), $H_{E}=0.183$ of the endemic and vulnerable Vellozia gigantea (Lousada et al., 2011), $H_{E}=0.12-0.14$ of Polylepis multijuga (Quinteros-Casaverde et al., 2012) and Polylepis incana $\left(H_{E}=0.13-0.17\right)$ currently classified as vulnerable (Hensen et al., 2011), $H_{E}=0.023$ of the vulnerable Bankouale' Palm Livistona carinensis (Shapcott et al., 2009), and $H_{E}=0.189$ of Gonystylus bancanus (Kusumadewi et al., 2010).

To promote programs for the conservation of vulnerable species, the over all genetic basis of its natural populations must be examined when formulating correct management decisions. Given that (1) there is still substantial genetic diversity in D. lowii, (2) According to our results, special attention needs to be given to conserve a private allele Got-1-e at Selat Nusa. The Parahangan population of greater genetic diversity was found $\left(A_{e}=2.50, H_{E}=0.73\right.$, $\left.H_{O}=0.59\right)$ than Selat Nusa population $\left(A_{e}=2.44\right.$, $\left.H_{E}=0.72, H_{O}=0.57\right)$. Nevertheless, Parahangan population exhibited lower number allelic per loci (3.25) than Selat Nusa population (3.50). So that, Selat Nusa population was the center genetic diversity of $D$. lowii. This population expected to enhance the effective management for genetic resources conservation in the future.

In conclusion, D. lowii in Central Kalimantan showed high genetic diversity and ranged $H_{E} 0,422$ (Hampangen population) up to 0,596 (Parahangan population). Most allozyme variation was found within population $(93.2 \%)$. Special attention is
I.J. Biotech.

essential to conserve a private allele of Got$1-e(9 \%)$ at Selat Nusa population. Sebangau population missed the alleles of Est-2- $b$ and Got-1- $a$, as found in other populations.

To forward for conservation of genetic resources from five populations studied were quite taken only one population is a Selat Nusa population. This population is expected to enhance the effective management for genetic resources conservation of this vulnerable species in the future.

\section{References}

Aguilar, R., Quesada, M., Ashworth, L., Herrerias-Diego, Y., and Lobo, J. 2008. Genetic consequences of habitat fragmentation in plant populations: susceptible signals in plant traits and methodological approaches. Mol Ecol 17:5177-5188.

Bacles, C.F., Lowe, A.J., and Ennos, R.A. 2006. Effective seed dispersal across a fragmented landscape. Science 311:628.

Barnaud A. and Houliston, E.G.C. 2010. Population genetics of the threatened tree daisy Olearia gardneri (Asteraceae), conservation of a critically endangered species. Conserv Genet 11:1515-1522.

Collevatti, R.G., Grattapaglia, D., and Hay, J.D. 2001. Population genetic structure of the endangered tropical tree species Caryocar brasiliense, based on variability at microsatellite loci. Mol Ecol 10:346-356.

Davies, S.J., Cavers, S., Finegan B., Navarro, C., and Lowe, A.J. 2010. Genetic consequences of multigenerational and landscape colonisation bottlenecks for a Neotropical Forest Pioneer Tree, Vochysia ferruginea. Tropical Plant Biol. (2010) 3:14-27.

Dawson, I.K., Lengkeek, A., Weber, J.C. and Jamnadass, R. 2009. Managing agroforestry ecosystems for improved conservation and enhanced livelihoods. Biodivers Conserv 18:969-986.

Dick, C.W. 2001. Genetic rescue of remnant tropical trees by an alien pollinator. Proc R Soc Lond Ser B Biol Sci 268:2391-2396. 
Wahyudiningsih et al.

Dick, C.W., Etchelecu, G., and Austerlitz, F. 2003. Pollen dispersal of tropical trees (Dinizia excelsa:fabaceae) by native insects and African honeybees in pristine and fragmented Amazoian rainforest $\mathrm{Mol}$ Ecol 12:753-764.

Dohong, A. 2008. Community-based peat swamp restoration in Block A north of the ex mega rice project in central Kalimantan. Paper presented at the Symposium on peat swamp forests. Towards enhancement of knowledgebased decision making in conservation and management of natural resources. Kuala Lumpur.

Donovan, D.G. and Puri, R.K. 2004. Learning from traditional knowledge of non-timber forest products: Penan Benalui and the autecology of Aquilaria in Indonesian Borneo. Ecol Soc 9:1-23.

Duminil, J., Hardy, O.J., and Petit, R.J. 2009. Plant traits correlated with generation time directly affect inbreeding depression and mating system and indirectly genetic structure. BMC Evol Biol 9:177.

Finkeldey, R. and Hattemer, H. 2007. Tropical forest genetics. Institute of Forest Genetics and Forest Tree Breeding. Göttingen. Germany.

Hamrick, J.L., Murawski, D.A. and Nason, J.D. 1992. The Influence of seed dispersal mechanisms on the genetic structure of tropical tree populations. Vegetatio 107(108):281-297.

Hamrick, J.L. and Godt, M.J.W. 1996a. Conservation genetics of endemic plant species. In: Avise, J.C., Hamrick, J.L. (Eds.): Conservation Genetics, Case Histories from Nature. Chapman and Hall, New York, pp. 281-304.

Hamrick, J.L. and Godt, M.J.W., 1996b. Effects of life history traits on genetic diversity in plant species. Philo. Trans. Roy. Soc. London. 351: 1291-1297.

Handadhari, T. 2004. Pohon Jelutung (Dyera spp.) tanaman dwiguna yang konservasionis dan menghidupi. Siaran pers no. S.504/II/ PIK-1/2004.
I.J. Biotech.

Kementerian Kehutanan Republik Indonesia.

Hanson, T.R., Brunsfeld, S.J., Finegan, B., and Waits, L.P. 2008. Pollen dispersal and genetic structure of the tropical tree Dipteryx panamensis in a fragmented Costa Rican landscape. Mol Ecol 17:2060-2073.

Harrison, M.E., Page, S.E., and Limin, S.H. 2009. The global impact of Indonesian forest fires. Biologist. Vol. 56 Number 3: 156-163.

Hartati, D., Rimbawanto, A., Taryono, Sulistyaningsih E. and Widyatmoko, A.Y.B.C. 2007. Pendugaan keragaman genetik Pulai menggunakan penanda RAPD. Jurnal Pemuliaan Tanaman Hutan 1 (2): 89-98.

Hughes, L., Dunlop, M., and French, K., 1994. Predicting dispersal spectra: a minimal set of hypotheses based on plant attributes. J. Ecol. 82, 933-950.

IUCN, 2010. The IUCN red list of vulnerable species, version 2010. http://www. iucnredlist.org.

Kusumadewi, Y., Poerba, Y.S., and Partomiharjo, T. 2010. Keragaman genetik Ramin (Gonystylus bancanus (Miq.) Kurz. dari Provinsi Riau berdasarkan profil random amplified polymorphic DNA. Jurnal Biologi Indonesia 6(2):173-183.

Le Guen, V., Doaré, F., Weber, C., and Seguin, M. 2009. Genetic structure of Amazonian populations of Hevea brasiliensis is shaped by hydrographical network and isolation by distance. Tree Genetics \& Genomes 5:673-683.

Lousada, J.M., Borba, E.L., Ribeiro, K.T., Ribeiro, L.C., and Lovato, M.B. 2011. Genetic structure and variability of the endemic and vulnerable Vellozia gigantea (Velloziaceae) associated with the landscape in the Espinhac,o Range, in southeastern Brazil: implications for conservation. Genetica 139:431-440.

Lowe, A., Stephen H., and Paul A. 2004. Ecological genetics: design, analysis and application. Blackwell Publishing. 
Wahyudiningsih et al.

Middleton, D.J. 2007. Flora Malesianan series I. Seed plants volume 18 . Apocynaceae (subfamilies rauvolfioideae and apocynoideae. Foundation Flora Malesiana. National Herbarium Netherland. p. 186-190.

Nei, M. 1972. Genetic distance between populations. American Naturalist 106: 283-292.

Nei, M. 1987. Moleculer evolutionary genetics. Columbia University Press, New York.

Quinteros-Casaverde, N., Flores-Negro'n, C.F., and Williams, D.A. 2012. Low genetic diversity and fragmentation effects in a windpollinated tree, Polylepis multijuga Plige (Rosaceae) in the high Andes. Conserv Genet 13:593-603.

Resende, L.C., Ribeiro, R.A., and Lovato, M.B. 2011. Diversity and genetic connectivity among populations of a threatened tree (Dalbergia nigra) in a recently fragmented landscape of the Brazilian Atlantic Forest. Genetica 139:1159-1168.

Ridgway, T., 2005. Allozyme eletrophoresis still represents a powerful technique in the management of coral reefs. Biodiv. Conserv. 14, 135-149.

Sedik, Y., Hamdan, S., Jusoh, I., and Hasan, M. 2010. Acoustic properties of selected tropical wood species. J Nondestruct Eval 29: 38-42.

Shapcott, A., Dowe, J.L., and Ford H. 2009. Low genetic diversity and recovery implications of the vulnerable Bankouale' Palm Livistona carinensis (Arecaceae), from North-eastern Africa and the Southern Arabian Peninsula. Conserv Genet 10:317-327.

Takahashi T., Tani N., Taira H., and Tsumura Y. 2005. Microsatellite markers reveal high allelic variation in natural populations of Cryptomeria japonica near refugial areas of the last glacial period. J Plant Res 118(2):83-90.

Tanaka, A., Ohtani, M., Suyama, Y., Inomata, N.,Tsumura, Y., Middleton, B.A., Tachida, H., and Kusumi, J. 2012. Population genetic structure of a widespread
I.J. Biotech.

coniferous tree, Taxodium distichum [L.] Rich. (Cupressaceae), in the Mississippi River Alluvial Valley and Florida. Tree Genetics E Genomes 8:1135-1147.

Torres-Díaz, C., Ruiz, E., González, F., Fuentes, G., and Cavieres, L.A., 2007. Genetic diversity in Nothofagus alessandrii (Fagaceae), an endangered endemic tree species of the coastal Maulino forest of central Chile. Ann. Bot. 100, 75-82.

Wendel, J.F. and Weeden, N.F. 1989. Visualization and interpretation of plant isozymes. In P. Soltis dan D. Soltis (eds.): 'Isozymes in Plant Biology'. vol 4, chapter 1, p. 5-45. Dioscorides Press. Portland.

Wright, S. 1951. The genetic structure populations. Annals of Eugenics, 15,32354.

Yeh, F.C. 1999. Population genetics. In A Young, D. Boshier dan T. Boyle (Eds): Forest concervation genetics, Principle and Practice. CABI Publishing.

Yule, C.M., 2010. Loss of biodiversity and ecosystem functioning in Indo-Malayan peat swamp forest. Biodivers Conserv 19:393-409. 